\title{
Pengaruh kualitas pelayanan biro akademik dan kemahasiswaan (BAK) terhadap kepuasan mahasiswa Universitas Trunojoyo Madura
}

\author{
Firsty Larastiyana Susanto, Ely Siswanto* \\ Universitas Negeri Malang, Jl. Semarang No. 5 Malang, Jawa Timur, Indonesia \\ *Penulis korespondensi, Surel: ely.siswanto.fe@um.ac.id
}

Paper received: 25-8-2021; revised: 8-9-2021; accepted: 15-9-2021

\begin{abstract}
To find out the level of quality of service that has been given to consumers or their customers, student and community satisfaction as users of academic administration services waws used as an indicator. The student satisfaction surveys conducted in this study aims to know the level of Madura Trunojoyo University students' satisfaction on the quality of academic administration services throughout the year 2021. This study used quantitative approach with survey method. The survey was carried out by making a closed questionnaire using Google form to investigate students' satisfaction. The questionnaire were then distributed online to students who previously used academic administrative services of the academic bureau and the student council of the Madura Trunojoyo University in 2021. The obtained 100 respondents represented an entire population that used the academic administration services of the academic bureau and student affairs in 2021. Results obtained in this study suggest that the quality service variable, especially in Financial Administration Bureau, has a significant impact on the satisfaction of the student Trunojoyo Madura University.
\end{abstract}

Keywords: academic service quality; academic bureau and the student council; student satisfaction

\begin{abstract}
Abstrak
Untuk mengetahui level kualitas servis yang diberikan kepada konsumen, kepuasan mahasiswa dan masyarakat, sebagai pengguna jasa administrasi akademik, digunakan sebagai sebuah indikator. Survei kepuasan mahasiswa pada penelitian ini bertujuan untuk menelusuri tingkat kepuasan mahasiswa di Universitas Trunojoyo Madura pada kualitas jasa administrasi akademik, selama 2021. Penelitian ini menggunakan pendekatan kuantitatif dengan metode survei. Survei dilakukan dengan menyebarkan kuesioner tertutup melalui Google Form untuk mengetahui tingkat kepuasan mahasiswa. Kuesioner tersebut kemudian didistribusikan secara daring kepada mahasiswa yang pernah menggunakan jasa layanan akademik dan dewan mahasiswa di Universitas Trunojoyo Madura pada 2021. Sebanyak 100 responden yang terkumpul mewakili seluruh populasi yang pernah menggunakan layanan biro akademik dan dewan mahasiswa pada 2021. Hasil dari penelitian ini menunjukkan bahwa variabel kualitas layanan, khususnya Biro Administrasi Keuangan, memiliki efek yang signifikan terhadap tingkat kepuasan mahasiswa Universitas trunojoyo Madura.
\end{abstract}

Kata kunci: kualitas pelayanan akademik; biro akademik dan kemahasiswaan; kepuasan mahasiswa

\section{Pendahuluan}

Sebagai salah satu jenis lembaga pendidikan perguruan tinggi dituntut untuk dapat memberikan pelayanan akademik maupun non-akademik yang berkualitas sesuai dengan harapan mahasiswa, serta masyarakat selaku konsumen pengguna layanan (Heslina, dkk:2017). Pelayanan administrasi akademik diberikan perguruan tinggi kepada mahasiswa, dan masyarakat pengguna layanan untuk mencapai tujuan akademik yang telah ditetapkan. Kualitas pelayanan administrasi akademik yang telah diberikan kepada mahasiswa selaku pengguna layanan administrasi akademik menentukan tingkat kepuasan mahasiswa, serta secara tidak langsung akan memberikan dampak baik bagi perguruan tinggi di masa 
mendatang. Sebagai contoh, apabila pelayanan yang telah diberikan oleh perguruan tinggi dapat membuat mahasiswa merasa puas, maka mereka akan berusaha untuk memberikan penilaian yang baik kepada masyarakat lain untuk terus menggunakan jasa perguruan tinggi tersebut. Hingga akhirnya hal tersebut dapat mempertahankan citra baik dari perguruan tinggi tersebut.

Perkembangan kepuasan dalam benak konsumen bergantung pada seberapa baik mereka selaku produsen dalam mempertahankan konsumen mereka yang kemudian menjadi pelanggan seiring berjalannya waktu melalui layanan yang mereka berikan. Dalam kasus ini, salah satu hal yang krusial untuk diperhatikan oleh suatu perguruan tinggi dalam mewujudkan citra yang lebih baik adalah kualitas pelayanan administrasi akademik (Mokodompit \& Luneto:2019). Menurut Setiawardani (2018) dalam penelitiannya mengenai Pengaruh Kualitas Pelayanan Administrasi terhadap Kepuasan Mahasiswa Politeknik Bandung, menjelaskan bahwa layanan merupakan salah satu upaya yang dilakukan produsen kepada konsumen ataupun pelanggan dalam rangka pemenuhan harapan mereka terhadap layanan yang mereka terima. Pelayanan administrasi akademik dapat dikatakan berkualitas apabila sesuai dengan kebutuhan pelanggannya (Sallis, dalam Mokodompit \& Luneto:2019).

Kualitas pelayanan yang baik mengarah pada kepuasan konsumen, dan pada akhirnya hal tersebut yang dapat membuat perguruan tinggi menjadi lebih kompetitif dalam persaingan pada bidang layanan pendidikan. Tingginya kualitas pelayanan dapat dicapai oleh perguruan tinggi dengan cara mengidentifikasi masalah yang terjadi dalam pemberian layanan terhadap mahasiswa sebagai konsumen, serta mengukur tingkat kinerja pelayanan untuk memenuhi harapan konsumen akan kualitas yang telah diterima dan dirasakannya hingga mencapai titik kepuasan konsumen tertentu. Oleh sebab itu, untuk mencari tahu tingkat kualitas pelayanan yang telah diberikan oleh suatu perguruan tinggi kepada konsumen atau pelanggannya, apakah telah sesuai dengan harapan mereka atau tidak, terdapat salah satu indikator utama yang digunakan, yaitu kepuasan mahasiswa dan masyarakat sebagai pengguna layanan administrasi akademik. Kepuasan konsumen dan kualitas pelayanan merupakan dua aspek yang krusial dalam bisnis.

Berdasarkan pada penjelasan Lovelock \& Wirtz (dalam Mahsyar \& Surapati:2020) mengenai kepuasan konsumen, dijelaskan bahwa konsumen mengikuti observasi hasil yang diperoleh dari suatu produk dan jasa, dan membandingkan kedua hal tersebut dengan suatu standar atau harapan yang telah ditetapkan sebelumnya, yang kemudian hal itu akan membentuk putusan kepuasan berdasarkan pada perbandingan tersebut. Kotler \& Keller (dalam Mahsyar \& Surapati:2020) juga memiliki gagasan serupa mengenai kepuasan konsumen yang menjelaskan bahwa kepuasan konsumen merupakan tingkatan perasaan seseorang yang timbul setelah membandingkan hasil dari suatu produk yang diterima dengan harapan mereka sebelumnya. Apabila hasil yang diterima lebih rendah dari yang diharapkan, kemudian konsumen akan merasa tidak puas akan layanan yang telah mereka terima. Sebaliknya, apabila hasil yang diterima sesuai dengan apa yang telah mereka harapkan sebelumnya, lalu konsumen akan merasa puas dengan layanan yang telah mereka terima tersebut. Bahkan konsumen akan merasa sangat puas apabila hasil yang diterima dapat melebihi harapan mereka.

Dalam hal ini, rendahnya tingkat kepuasan mahasiswa sebuah perguruan tinggi disebabkan oleh adanya celah antara pemenuhan kualitas yang diharapkan dengan pelayanan 
yang telah mereka terima. Hal itu terlihat dari masih terdapat banyak keluhan terhadap layanan administrasi akademik yang disampaikan melalui berbagai media mengenai kinerja pelayanan administrasi akademik yang mereka dapatkan, hingga hal tersebut dapat berdampak buruk bagi citra perguruan tinggi. Mengingat fungsi utama perguruan tinggi sebagai lembaga pendidikan adalah melayani masyarakat (mahasiswa), maka perlu dilakukan adanya perbaikan serta peningkatan kualitas pelayanan yang terkait dengan layanan administrasi akademik kepada mahasiswa pengguna layanan tersebut.

Universitas Trunojoyo Madura sebagai salah satu perguruan tinggi yang berlokasi di Pulau Madura tepatnya di Kota Bangkalan, Jawa Timur, memiliki beberapa tujuan yang telah ditetapkan sebelumnya. Namun, untuk mencapai tujuan tersebut diperlukan manajemen yang baik dalam perencanaan mengenai apa saja yang perlu dilakukan, hingga pengawasan dalam implementasi rencana yang telah ditetapkan sebelumnya. Mustahil jika tidak ditemukan adanya suatu masalah dalam implementasi rencana yang telah ditetapkan oleh Universitas Trunojoyo Madura untuk mencapai tujuannya, terutama dalam pemberian layanan administrasi akademik khususnya kepada mahasiswa pengguna layanan tersebut. Sehingga, diperlukan tindakan observasi, dan evaluasi untuk mengetahui kualitas pelayanan administrasi akademik yang berdampak pada kepuasan mahasiswa, dan masyarakat pengguna layanan tersebut.

Kurangnya perhatian pihak kampus terhadap pemeliharaan serta perbaikan kinerja layanan administrasi yang diberikan kepada mahasiswa dalam hal ini merupakan konsumen yang menikmati sekaligus merasakan layanan tersebut, sehingga diperlukannya salah satu cara yang dapat dilakukan oleh perguruan tinggi untuk mengetahui tingkat kualitas pelayanan administrasi akademik, khususnya pada Biro Akademik dan Kemahasiswaan (BAK), yaitu dengan cara melakukan sebuah survei kepuasan mahasiswa Universitas Trunojoyo Madura terhadap pelayanan administrasi akademik Biro Akademik dan Kemahasiswaan (BAK) pada tahun 2021, sebagai bahan evaluasi untuk menentukan kebijakan dalam rangka perbaikan, maupun peningkatan kualitas pelayanan kepada mahasiswa di masa mendatang.

Sebagai bentuk tindak lanjut untuk mengetahui tingkat kepuasan mahasiswa Universitas Trunojoyo Madura terhadap kualitas pelayanan akademik pada Biro Akademik dan Kemahasiswaan (BAK), sebuah survei kepuasan mahasiswa dilakukan dalam penelitian ini dengan tujuan untuk mengetahui tingkat kepuasan mahasiswa Universitas Trunojoyo Madura sebagai responden terhadap kualitas pelayanan administrasi akademik sepanjang tahun 2021. Kemudian, hasil survei tersebut dapat dijadikan sebagai bahan evaluasi bagi pihak universitas terkait, khususnya pada bagian Biro Akademik dan Kemahasiswaan (BAK) dalam membuat keputusan berupa perbaikan, maupun peningkatan kinerja pelayanan administrasi akademik kepada mahasiswa sebagai konsumen dalam ruang lingkup kampus.

\section{Metode}

Jenis pendekatan yang digunakan dalam penelitian ini adalah metode penelitian kuantitatif dengan menggunakan penelitian survei. Salah satu karakteristik penelitian kuantitatif, yaitu menggambarkan masalah penelitian melalui deskripsi yang menjelaskan hubungan antar variabel dengan menginvestigasi masalah penelitian melalui kondisi di lapangan, dan menjelaskan mengapa sesuatu terjadi. Sedangkan, penelitian survei ialah penelitian yang digunakan untuk menjelaskan hubungan kausal dan pengujian hipotesis. Penelitian survei dilakukan dengan cara membuat kuesioner tertutup memanfaatkan Google 
Form sebagai salah satu alat untuk mendapatkan responden pada survei kepuasan mahasiswa dalam penelitian ini yang kemudian disebarkan secara daring kepada mahasiswa yang pernah menggunakan layanan administrasi akademik Biro Akademik dan Kemahasiswaan (BAK) Universitas Trunojoyo Madura pada tahun 2021.

Skala pengukuran menggunakan skala Likert. Skala ini berhubungan dengan pernyataan tentang pendapat, persepsi dan sikap responden terhadap pelayanan akademik. Kuesioner yang disebarkan menggunakan skala pengukuran Skala Likert, berisi lima skala pengukuran (Sangat Setuju, Setuju, Netral, Tidak Setuju, Sangat Tidak Setuju, serta Sangat Puas, Puas, Cukup Puas, Kurang Puas, dan Sangat Kurang Puas) sebagai bentuk jawaban pada tiap butir pernyataan yang telah disediakan. Pengambilan sampel menggunakan teknik non-probability sampling, sehingga tiap unsur yang terdapat dalam populasi tidak memiliki kesempatan atau peluang yang sama untuk dipilih sebagai sampel, bahkan kemungkinan anggota populasi tertentu untuk terpilih tidak dapat diketahui (Siregar, 2013:33).

Metode purposive sampling digunakan dalam penetapan responden yang akan dijadikan sebagai sampel berdasarkan pada kriteria-kriteria tertentu (Siregar, 2013:33). Data yang diperoleh dari penelitian ini kemudian dianalisis menggunakan alat bantu perangkat lunak IBM SPSS Statistics 20. Penggunaan teknik analisis regresi linear sederhana diharapkan dapat menggambarkan hubungan serta pengaruh dari variabel independen terhadap variabel dependen dalam penelitian ini. Setelah melakukan uji regresi linear sederhana, kemudian dilanjutkan dengan pengujian statistik yang terdiri dari uji $\mathrm{t}$, dan koefisien determinasi $(R$ Square).

\section{Hasil dan Pembahasan}

Dari hasil penjelasan yang telah dipaparkan pada bagian pendahuluan dan metode di atas, diperoleh sampel sebanyak 100 orang responden mewakili keseluruhan populasi yang pernah menggunakan layanan administrasi akademik Biro Akademik dan Kemahasiswaan (BAK) pada tahun 2021. Responden yang diperoleh berasal dari angkatan 2016-2021. Sebaran responden yang merupakan angkatan 2019 memiliki persentase sebesar 31\%, selanjutnya disusul oleh angkatan 2020 dengan persentase sebesar 26\%, Lalu, pada posisi ketiga terdapat mahasiswa yang berasal dari angkatan 2018 dengan persentase sebesar 11\%, dan seterusnya. 


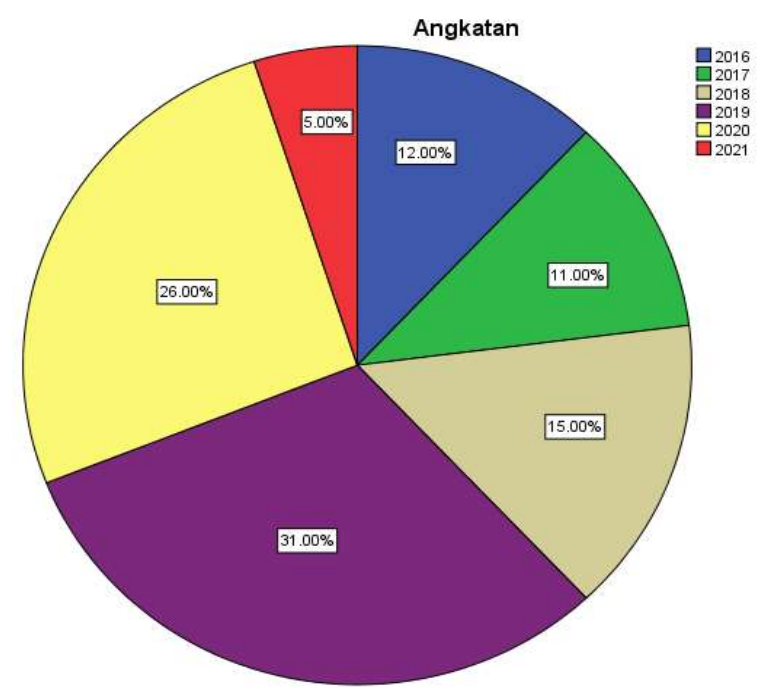

\section{Gambar 1. Grafik Persentase Responden Penelitian Berdasarkan Angkatan}

Nilai konstanta (a) yang terdapat pada Tabel 1 di bawah ini menunjukkan angka sebesar -5,870 yang berarti bahwa tingkat kepuasan mahasiswa dalam kualitas pelayanan sebesar 5,870. Sedangkan, koefisien regresi X sebesar 0,383 menyatakan bahwa variabel kualitas pelayanan bertanda positif terhadap kepuasan mahasiswa sebesar 0,383 . Bertambahnya satu nilai kualitas pelayanan berdampak pada pertambahan nilai kepuasan mahasiswa sebesar 0,383 .

Tabel 1. Analisis Regresi Linear Sederhana

\begin{tabular}{|c|c|c|c|c|c|c|c|c|}
\hline \multirow{2}{*}{\multicolumn{2}{|c|}{ Model }} & \multicolumn{2}{|c|}{$\begin{array}{l}\text { Unstandardize } \\
\text { d Coefficients }\end{array}$} & \multirow{2}{*}{$\begin{array}{l}\begin{array}{l}\text { Standardized } \\
\text { Coefficients }\end{array} \\
\text { Beta }\end{array}$} & \multirow[t]{2}{*}{$\mathrm{t}$} & \multirow[t]{2}{*}{ Sig. } & \multicolumn{2}{|c|}{$\begin{array}{l}95.0 \% \\
\text { Confidence } \\
\text { Interval for B }\end{array}$} \\
\hline & & B & $\begin{array}{l}\text { Std. } \\
\text { Error }\end{array}$ & & & & $\begin{array}{l}\text { Lower } \\
\text { Bound }\end{array}$ & $\begin{array}{l}\text { Upper } \\
\text { Bound } \\
\end{array}$ \\
\hline \multirow[b]{2}{*}{1} & (Constant) & -5.870 & 1.290 & & -4.549 & .000 & -8.430 & -3.309 \\
\hline & $\begin{array}{l}\text { Kualitas } \\
\text { Pelayanan }\end{array}$ & .383 & .027 & .824 & 14.403 & .000 & .330 & .435 \\
\hline
\end{tabular}

Dependent Variable: Kepuasan Mahasiswa

Pengaruh antara variabel kualitas pelayanan dengan variabel kepuasan mahasiswa dapat dilihat dari nilai signifikan tiap variabel. Dari hasil perhitungan data pada Tabel 3 diketahui bahwa nilai $\mathrm{T}_{\text {hitung }}$ lebih besar dari $\mathrm{T}_{\text {tabel }}$ atau 14,403 > 1,988 dan nilai signifikan yang dihasilkan sebesar 0,000 lebih kecil dari 0,05. Dengan begitu, Ha diterima, dan Ho ditolak, yang berarti bahwa variabel kualitas pelayanan berpengaruh signifikan terhadap kepuasan mahasiswa. 
Tabel 3. Uji t pada Hipotesis

\begin{tabular}{|c|c|c|c|c|c|c|c|c|}
\hline \multirow{2}{*}{\multicolumn{2}{|c|}{ Model }} & \multicolumn{2}{|c|}{$\begin{array}{l}\text { Unstandardize } \\
\text { d Coefficients }\end{array}$} & \multirow{2}{*}{$\begin{array}{l}\text { Standardized } \\
\text { Coefficients } \\
\text { Beta }\end{array}$} & \multirow[t]{2}{*}{$\mathrm{t}$} & \multirow[t]{2}{*}{ Sig. } & \multicolumn{2}{|c|}{$\begin{array}{l}95.0 \% \\
\text { Confidence } \\
\text { Interval for B }\end{array}$} \\
\hline & & B & $\begin{array}{l}\text { Std. } \\
\text { Error }\end{array}$ & & & & $\begin{array}{l}\text { Lower } \\
\text { Bound }\end{array}$ & $\begin{array}{l}\text { Upper } \\
\text { Bound }\end{array}$ \\
\hline \multirow[b]{2}{*}{1} & (Constant) & -5.870 & 1.290 & & -4.549 & .000 & -8.430 & -3.309 \\
\hline & $\begin{array}{l}\text { Kualitas } \\
\text { Pelayanan }\end{array}$ & .383 & .027 & .824 & 14.403 & .000 & .330 & .435 \\
\hline
\end{tabular}

a. Dependent Variable: Kepuasan Mahasiswa

Tabel 4. Uji Koefiensi Determinasi ( $R$ Square)

\begin{tabular}{lllllllllll}
\hline Model & $\mathrm{R}$ & $\mathrm{R}$ & Adjusted & Std. Error & Change Statistics \\
& & Square & R Square & $\begin{array}{l}\text { Of the } \\
\text { Estimate }\end{array}$ & $\begin{array}{l}\text { R } \\
\text { Square } \\
\text { Change }\end{array}$ & F Change df1 & df2 & $\begin{array}{l}\text { Sig. F } \\
\text { Change }\end{array}$ \\
\hline 1 & $.824^{\mathrm{a}}$ & .679 & .676 & 1.149 & .679 & 207.447 & 1 & 98 & .000 \\
\hline
\end{tabular}

a. Predictors: (Constant), Kualitas Pelayanan

b. Dependent Variable: Kepuasan Mahasiswa

Pada tabel di atas diketahui bahwa nilai Adjusted $R$ Square sebesar 0,676 atau 67,6\%. Hal itu menggambarkan adanya pengaruh antar variabel sebesar 67,6\%. Sedangkan, 32,4\% dipengaruhi oleh faktor lain di luar penelitian ini.

Dalam hal pemenuhan harapan konsumen tidak jarang ditemukan adanya ketidaksesuaian antara harapan konsumen dengan kualitas aktual yang dirasakan setelah memperoleh layanan dari suatu unit pelayanan, seperti yang dijelaskan oleh Rangkuti (dalam Wijaya:2017) mengenai kepuasan pelanggan sebagai respon pelanggan terhadap ketidaksesuaian antara tingkat kepentingan dan kinerja aktual yang dirasakan setelah pemakaian. Seperti penelitian yang telah dilakukan sebelumnya oleh Rahareng \& Relawan (2017) yang menjelaskan bahwa kualitas pelayanan yang terdiri dari lima indikator di dalamnya memiliki pengaruh yang secara simultan berpengaruh terhadap kepuasan mahasiswa. Dalam hal ini, berdasarkan hasil analisis yang diperoleh dalam penelitian ini dapat dibuktikan bahwa kualitas pelayanan dapat mempengaruhi tingkat kepuasan mahasiswa yang menggunakan layanan tersebut.

Didukung dengan penelitian lain dalam bidang pendidikan yang dilakukan oleh Annamdevula \& Bellamkonda (dalam Chandra, Ng, Chandra, \& Priyono: 2018) di India menunjukkan adanya hubungan positif antara kualitas pelayanan dan kepuasan mahasiswa yang mengindikasikan bahwa meningkatnya kualitas pelayanan yang diberikan dapat meningkatkan kepuasan mahasiswa. Chandra, Ng, Chandra, \& Priyono (2018) juga menempatkan perhatian serius pada kualitas pelayanan yang diberikan oleh perguruan tinggi di Provinsi Riau yang dirasa sangat diperlukan karena makin baik kualitas pelayanan yang diberikan, makin tinggi pula tingkat kepuasan mahasiswa.

Penelitian serupa di bidang lain, yaitu bidang industri dilakukan oleh Agyapong (2011) yang melakukan penelitian untuk mengetahui efek dari kualitas pelayanan pada kepuasan pelanggan dalam bidang industri. Dalam penelitian tersebut dijelaskan bahwa terdapat sebuah 
hubungan positif antara kualitas pelayanan dengan kepuasan pelanggan. Analisis regresi berganda dilakukan dengan tujuan untuk menguji hubungan antara kedua variabel tersebut, dan hasilnya menunjukkan bahwa seluruh item dalam kualitas pelayanan merupakan prediktor yang baik dalam menentukan tingkat kepuasan pelanggan.

Berdasarkan hasil pada penelitian yang telah dilakukan, dapat diketahui bahwa kualitas pelayanan memiliki pengaruh yang cukup besar dalam menentukan tingkat kepuasan konsumen pada berbagai bidang di lingkungan masyarakat, khususnya pada bidang pendidikan. Mahasiswa merupakan konsumen sekaligus pelanggan yang harus dipuaskan oleh perguruan tinggi dalam hal layanan yang diberikan. Dalam pemberian layanan kepada mahasiswa, perguruan tinggi perlu mengetahui faktor apa yang dapat menentukan tingkat kepuasan mahasiswa. Pihak perguruan tinggi harus melakukan evaluasi sistem pelayanan yang ada secara berkala, indikator apa yang perlu diperbaiki, atau yang perlu dipertahankan.

Sehingga, kepuasan mahasiswa atas pelayanan yang diberikan dapat terus meningkat. Diperlukan sistem pelayanan akademik yang baik dalam mengelola suatu lembaga pendidikan, yang mampu memberikan kepuasan kepada para mahasiswa sebagai pengguna layanan. Kepuasan yang dirasakan oleh mahasiswa atas layanan berkualitas yang diperoleh diharapkan dapat meningkatkan motivasi belajar mahasiswa serta citra perguruan tinggi. Dalam hal ini, Biro Akademik dan Kemahasiswaan Universitas Trunojoyo Madura sebaiknya memperhatikan aspek kualitas pelayanan yang diberikan kepada mahasiswa setempat, sebab apabila kualitas pelayanan yang diberikan sudah cukup baik, maka hal itu dapat meningkatkan tingkat kepuasan mahasiswa.

\section{Simpulan}

Dalam kualitas pelayanan menyangkut hal kepuasan pengguna layanan tersebut. Salah satunya dalam hal pelayanan administrasi akademik yang diberikan oleh pihak perguruan tinggi kepada mahasiswa selaku pengguna layanan. Hasil penelitian menyatakan bahwa variabel kualitas pelayanan, khususnya pada BAK, berpengaruh signifikan terhadap kepuasan mahasiswa Universitas Trunojoyo Madura. Hal itu dapat dibuktikan dengan hasil analisis uji regresi linear sederhana yang menyatakan bahwa variabel kualitas pelayanan secara signifikan berpengaruh positif terhadap kepuasan mahasiswa sebesar 0,383. Sedangkan, pada uji t diperoleh hasil berupa variabel kualitas pelayanan berpengaruh signifikan terhadap kepuasan mahasiswa karena nilai $\mathrm{T}_{\text {hitung }}$ lebih besar dari $\mathrm{T}_{\text {tabel }}$ atau $14,403>1,988$. Angka tersebut mengindikasikan bahwa pelayanan akademik secara signifikan berpengaruh terhadap kepuasan mahasiswa Universitas Trunojoyo Madura.

Dalam hasil tersebut terlihat jelas bahwa kualitas pelayanan akademik sangat mempengaruhi tingkat kepuasan mahasiswa. Sehingga, disarankan kepada seluruh petugas yang bertugas di Biro Akademik dan Kemahasiswaan (BAK) Universitas Trunojoyo Madura untuk meningkatkan, dan menjaga kualitas pelayanan administrasi akademik dengan baik terhadap mahasiswa sebagai konsumen sekaligus pelanggan yang menikmati layanan administrasi akademik dalam ruang lingkup universitas. Karena salah satu faktor yang dapat mempengaruhi tingkat kepuasan mahasiswa yaitu, kualitas pelayanan yang diterima oleh mahasiswa dari layanan administrasi akademik di universitas. 


\section{Daftar Rujukan}

Agyapong, G. K. (2011). The Effect of Service Quality on Customer Satisfaction in the Utility Industry: A Case of Vodafone (Ghana). International Journal of Business and Management, 6(5).

Chandra, T., Ng, M., Chandra, S., \& Priyono. (2018). The Effect of Service Quality on Student Satisfaction and Student Loyalty: An Empirical Study. Journal of Social Studies Education Research, 9(3).

Heslina., Mus, A. M., Pettipeiluhu, J., Gladys, Y., \& Prenregngi, A., I. (2017). Pengaruh Kualitas Pelayanan Akademik dan Non Akademik Terhadap Kepuasan Mahasiswa Program Studi Manajemen STIEM Bongaya. Jurnal Ilmiah Bongaya (Manajemen \& Akuntansi), 41-48.

Mahsyar, S., \& Surapati, U. (2020). Effect of Service Quality and Product Quality on Customer Satisfaction and Loyalty. International Journal of Economics, Business and Accounting Research, 4(1).

Mokodompit, F., \& Luneto, B. (2019). Pengaruh Persepsi dan Kualitas Pelayanan Akademik Terhadap Kepuasan Mahasiswa. Al-Minhaj: Jurnal Pendidikan Islam, 2(1).

Rahareng, V. J., \& Relawan, N. (2017). Pengaruh Kualitas Pelayanan Akademik terhadap Kepuasan Mahasiswa: Studi pada Mahasiswa Administrasi Bisnis Universitas Telkom. Jurnal AdBispreneur, 2(2).

Setiawardani, M. (2018). Pengaruh Kualitas Pelayanan Administrasi Terhadap Kepuasan Mahasiswa Politeknik Bandung. Jurnal Riset Bisnis dan Investasi, 4(1).

Siregar, S. (2013). Metode Penelitian Kuantitatif: Dilengkapi dengan Perbandingan Perhitungan Manual \& SPSS. Jakarta: Kencana.

Wijaya, S. (2017). Analisis Tingkat Kepuasan Mahasiswa terhadap Pelayanan Bagian Keuangan dengan Metode Customer Satisfaction Index. Jurnal Ilmiah Rekayasa dan Manajemen Sistem Informasi, 3(1). 